\title{
Combined dextran and ficoll separation yields pure populations of chicken peripheral blood mononuclear cells - short communication
}

\author{
Mladen Jergovićc ${ }^{\# 1}$, Gordana Nedeljkovićc ${ }^{\# 2}$, Željko Cvetić2 \\ Željko Gottstein ${ }^{2}$, and Krešo Bendelja ${ }^{1 *}$ \\ ${ }^{I}$ Centre for Research and Transfer of Knowledge in Biotechnology, University of Zagreb, Zagreb, Croatia \\ ${ }^{2}$ Department of Poultry Diseases with Clinic, Faculty of Veterinary Medicine, University of Zagreb, \\ Zagreb, Croatia
}

\begin{abstract}
JERGOVIĆ, M., G. NEDELJKOVIĆ, Ž. CVETIĆ, Ž. GOTTSTEIN，K. BENDELJA: Combined dextran and ficoll separation yields pure populations of chicken peripheral blood mononuclear cells - short communication. Vet. arhiv 87, 623-630, 2017.

\section{ABSTRACT}

The ficoll density gradient method, the most widely used method for isolating avian peripheral blood mononuclear cells (PBMCs), results in significant contamination with nucleated thrombocytes. This thrombocyte contamination can affect both immunophenotyping and functional assays of $\mathrm{T}$ cells. We used full blood samples from ten vaccinated male layer hybrid chickens for isolating PBMCs, and have developed a low cost, combined dextran and ficoll density gradient separation method which, in comparison to the standard ficoll density gradient separation, markedly reduces thrombocyte contamination of the isolated PBMCs. An ex vivo $\mathrm{T}$ cell proliferation assay showed an overall reduced background proliferation in unstimulated and stimulated samples after combined dextran and ficoll separation of PBMCs, resulting in a statistically significant difference upon in vitro NDV challenge.
\end{abstract}

Key words: dextran, ficoll, chicken, thrombocytes, peripheral blood mononuclear cells

* equally contributing first authors

\section{Introduction}

Immunophenotyping (BEIRÃO et al., 2012; FAIR and TAYLOR-McCABE, 2008) and functional ex vivo analyses of $\mathrm{T}$ cell responses (DALGAARD et al., 2010a) are used to

\footnotetext{
${ }^{*}$ Corresponding author:

Krešo Bendelja, Centre for Research and Transfer of Knowledge in Biotechnology, University of Zagreb, Rockfellerova 10, Zagreb, Croatia, Phone: +385 1641 4386; E-mail: kbendelja@gmail.com
} 
assess responses to infections and vaccination in poultry. Functional T cell assays require efficient isolation of peripheral blood mononuclear cells (PBMCs), but this is not necessary if phenotyping of lymphocytes and monocytes is done without downstream functional assays (SELIGER et al., 2012). Isolation of PBMCs in avian species is complicated by significant contamination with nucleated thrombocytes. The standard ficoll density gradient method is effective in separating erythrocytes and granulocytes from PBMCs, but not thrombocytes. One previous study (LAVOIE and GRASMAN, 2005) described an alternative slow spin centrifugation method, which yielded purer lymphocyte populations, but required at least $4 \mathrm{~mL}$ of blood. Thrombocytes can be phenotypically distinguished from PBMCs in two different ways. In comparison to lymphocytes in peripheral blood (PBLs), thrombocytes express lower levels of antigen CD45 (De BOEVER et al., 2010), and a lack of CD3 surface antigen $\left(\mathrm{CD}^{4} 5^{\text {tow }} \mathrm{CD} 3^{-}\right)$. On the other hand, they express the K1 marker, just like monocytes and macrophages, but they lack a monocyte/macrophage Kul-01 marker

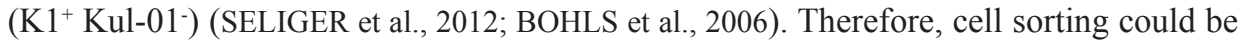
considered as the method of choice to remove thrombocyte contamination from PBLs, but it is expensive and requires additional equipment. Dextran sedimentation is routinely used for isolation of neutrophils and monocytes from mammalian peripheral blood (LUO et al., 2010; SUSTROVA et al., 2014). Here we present low cost, combined dextran slow spin centrifugation and ficoll density gradient separation which, in comparison to ficoll separation alone, yields purer populations of chicken PBMCs, especially lymphocytes. This may allow improved detection of antigen specific chicken $\mathrm{T}$ cell responses.

\section{Materials and methods}

Animals used. In this trial, ten peripheral blood samples of at least $2 \mathrm{~mL}$ were collected via jugular venepuncture into $4 \mathrm{~mL}$ polystyrene tubes (Falcon, BD Biosciences, Franklin Lakes, USA) containing Na-heparin. Eleven-week-old, vaccinated male chickens of the commercial layer hybrid Tetra SL "LL" ("Long life"; Bábolna Tetra Ltd, Bábolna, Hungary) were used. Primary immunisation of chickens against Newcastle disease was done at the age of 4 weeks by oculonasal application of a live NDV strain ZG1999HDS (Croatian lentogenic field strain isolated in the outbreak of 1999) or a commercial vaccine containing an NDV strain LaSota (Pestikal ${ }^{\circledR}$ LaSota SPF, Genera, Kalinovica, Croatia). A subsequent booster dose of commercial LaSota vaccine (Pestikal ${ }^{\circledR}$ LaSota SPF) was applied by the same route to all chickens at the age of 8 weeks. All the procedures with animals were done in compliance with the legislation on animal welfare (Animal Protection Law (Official Gazette 135/06; 37/13) and were approved by the Ethics Committee of the Faculty of Veterinary Medicine, Zagreb.

Isolation of chicken peripheral blood mononuclear cells (PBMCs). Heparinised chicken blood samples were divided into two tubes (polystyrene, $4 \mathrm{~mL}$, BD Biosciences), 
with $1 \mathrm{~mL}$ in each tube, and diluted 1:1 with phosphate-buffered saline (PBS, $\mathrm{pH}=$ 7.2-7.4, Imunološki Zavod, Zagreb, Croatia). For the combined dextran and ficoll density gradient PBMC separation, diluted blood was mixed with sterile 3\% dextran T-500 solution (GE Healthcare Bio-Sciences, Uppsala, Sweden) in a ratio of 1:0.4 and centrifuged at 50 $\times g$ for $10 \mathrm{~min}$. Upon centrifugation, two layers could be observed. The upper layer, containing PBMCs was carefully collected, layered onto an equal volume of ficoll (Histopaque ${ }^{\circledR}-1077$, Sigma-Aldrich, St. Louis, USA) and centrifuged at $900 \times \mathrm{g}$ for $30 \mathrm{~min}$. For the standard ficoll density gradient separation alone, diluted full blood samples were overlaid onto equal volumes of ficoll, and further treated in the same way as the combined dextran and ficoll samples. The buffer layer was collected at the interface of the plasma and ficoll, transferred to new tubes and washed twice with PBS by centrifugation at $400 \times \mathrm{g}$ for 10 min. Cells were counted under a light microscope using a Neubauer improved chamber.

Immunophenotyping and proliferation assays. For immunophenotyping, 250,000 cells were stained with leucocyte panel of monoclonal mouse anti chicken- CD45-APC (clone LT40); -CD3-SPRD (clone CT-3), and -Mo-Mf - R-PE (clone KUL 01) antibodies (Southern Biotech, Birmingham, USA) in staining buffer (1\% FCS, $0.1 \% \mathrm{NaN}_{3}$ in Dulbecco PBS, pH 7.4-7.6, Imunološki Zavod, Zagreb, Croatia). After exclusion of doublets, debris and the small number of remaining erythrocytes and granulocytes by forward and side scatter, at least 20,000 cells were acquired in the lymphocyte region, on a LSRII flow cytometer (BD Biosciences).

For proliferation assay, $2 \times 10^{6}$ cells per sample were stained with $5 \mathrm{mM}$ CellTrace Violet (CTV) dye (Life Technologies, Carlsbad, USA), transferred in cell culture media (RPMI 1640 with $10 \%$ FCS), split into 2 wells of 24 -well tissue culture plates (BD Biosciences), and incubated at $41{ }^{\circ} \mathrm{C}$ and $5 \% \mathrm{CO}_{2}$ overnight. The following day $1 \times 10^{6}$ cells were stimulated with the inactivated NDV vaccine strain LaSota, as described by NORUP et al. (2011) and the other $1 \times 10^{6}$ cells were left unstimulated (only media added). After 4 days of cultivation in a $\mathrm{CO}_{2}$ incubator at $41{ }^{\circ} \mathrm{C}$ and $5 \% \mathrm{CO}_{2}$, the cells were transferred to FACS tubes and 250,000 cells were stained with Fixable Viability Dye eFluor ${ }^{\circledR} 506$ (Life Technologies) and an antibody cocktail containing CD3-SPRD (clone CT-3), CD4-PE (clone CT-4), CD8-FITC (clone EP72) and gd TCR -UNLB *Alexa Fluor 647 (clone TCR-1) (Southern Biotech). After exclusion of doublets, debris and dead cells, at least 20,000 events, with size and granularity matching lymphocytes, were acquired by flow cytometer. Multiparametric data analysis was performed using FlowJo software (Version 7.6.5, Tree Star, Inc., Ashland, OR, USA).

Statistical analyses. Normality of distribution of all variables was assessed by Shapiro-Wilk's test. Since distribution of all variables was normal, the paired samples $\mathrm{T}$ test was used to compare the phenotype and $\mathrm{T}$ cell proliferation response of the same chickens, after ficoll-gradient separation alone, and combined dextran/ficoll gradient 
M. Jergović et al.: Combined dextran and ficoll separation reduces thrombocyte contamination in isolated chicken peripheral blood mononuclear cells

separation. All the statistical analyses were done by SPSS 18 software (IBM. Armonk, USA).

\section{Results and discussion}

Our method of combined dextran/ficoll gradient separation yielded purer populations of chicken PBMCs than ficoll gradient separation alone, due to the significantly reduced thrombocyte fraction (Fig. 1). The additional dextran separation step significantly reduced the number of cells obtained (ficoll alone: $119 \times 10^{6} \pm 37.1 \times 10^{6} / \mathrm{mL}$ of blood v. dextran/ficoll: $10 \times 10^{6} \pm 1.8 \times 10^{6} / \mathrm{mL}$ of blood; $\left.\mathrm{P}=0.005\right)$, but enough purified cells for immunophenotyping and functional assays could be obtained from only $1 \mathrm{~mL}$ of whole blood of very young chickens. The presence of abundant nucleated thrombocytes in PBMCs interferes with quantification of avian leukocyte populations, and requires an additional staining (anti K1 specific and anti K55) for exclusion of thrombocytes (SELIGER et al., 2012; BOHLS et al., 2006). Thus, our combined dextran/ficoll gradient separation could improve immunophenotyping simply by increasing the percentage of lymphocytes within PBMCs, which could be of great importance for rare subpopulations of lymphocytes (Fig. 1A).
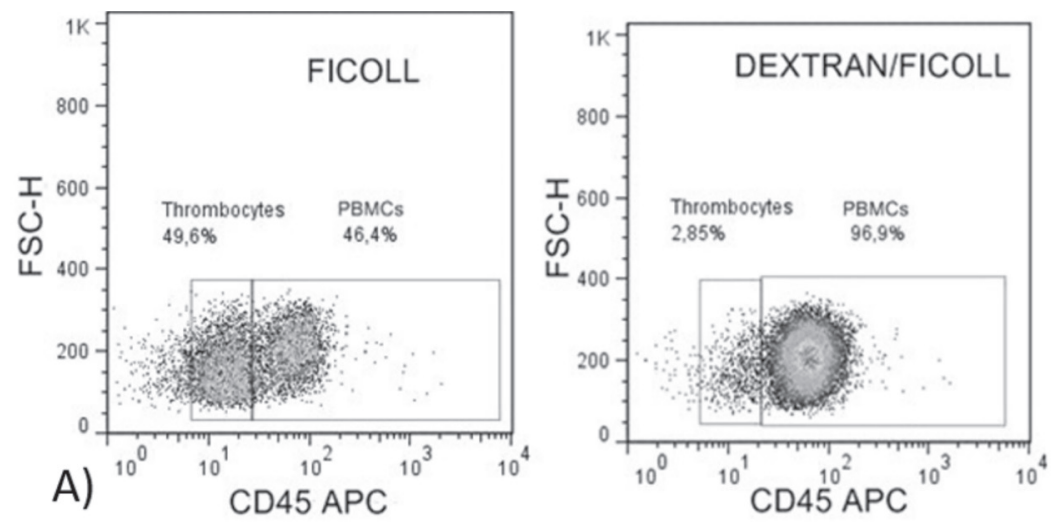

Fig. 1A. Immunophenotyping of PBMCs

Thrombocyte contamination was reduced after dextran/ficoll separation $(4.15 \% \pm 1.28 \%)$ compared to ficoll gradient separation alone $(55.56 \% \pm 4.3 \%)$ and enriched populations of PBMCs were obtained (93.92 $\pm 1.8 \%$ compared to $36.98 \pm 3.38 \%$ respectively). Both $\mathrm{P}$ values were $<0.05$. (A) Dot-plot diagram (CD45-APC vs. FSC) of representative sample showing the number of thrombocytes (CD45 low $)$ and PBMCs $\left(C D 45^{+ \text {high }}\right)$ assessed by CD45 expression. 
M. Jergović et al.: Combined dextran and ficoll separation reduces thrombocyte contamination in isolated chicken peripheral blood mononuclear cells

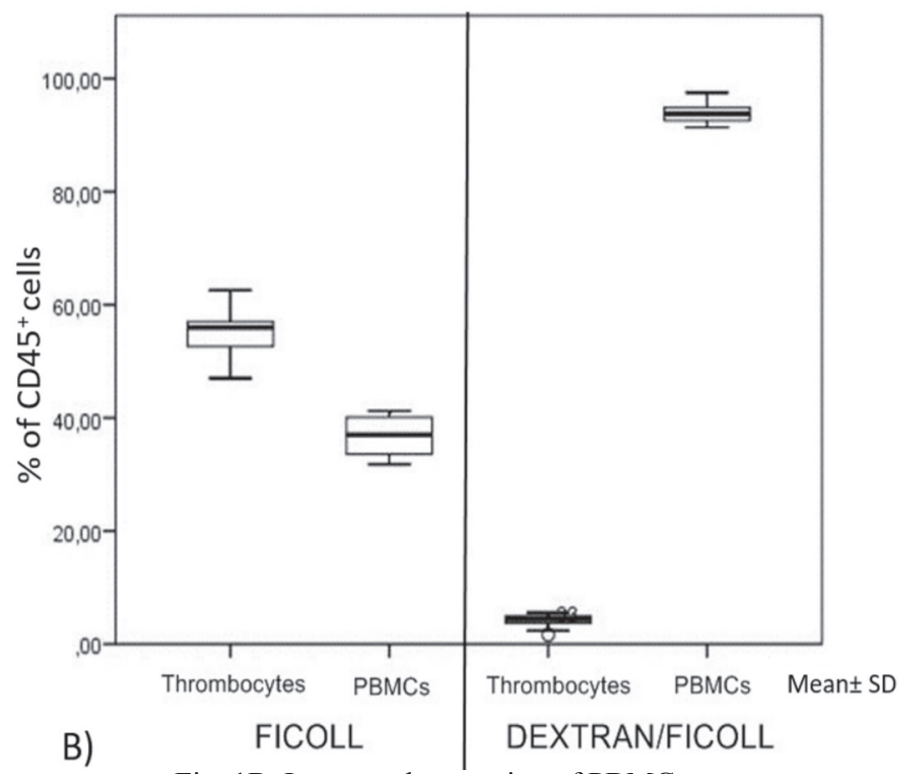

Fig. 1B. Immunophenotyping of PBMCs

Thrombocyte contamination was reduced after dextran/ficoll separation $(4.15 \% \pm 1.28 \%)$ compared to ficoll gradient separation alone $(55.56 \% \pm 4.3 \%)$ and enriched populations of PBMCs were obtained (93.92 $\pm 1.8 \%$ compared to $36.98 \pm 3.38 \%$ respectively). Both $\mathrm{P}$ values were $<0.05$. (B) Box plot diagram of reduction in thrombocyte number, expressed by mean $\pm \mathrm{SD}$. In total, isolated PBMCs from 10 chicken peripheral blood samples, $1 \mathrm{~mL}$ per method, were used. Cells were stained using Leucocyte panel antibodies: CD45-APC, Monocyte/Macrophage-R-PE, CD3-SPRD.

More importantly, our combined dextran/ficoll gradient separation further improves ex vivo $\mathrm{T}$ cell proliferation assay by reducing background proliferation. As shown in Fig. 2 , T cell proliferation assay, using CTV dye after ficoll gradient separation alone resulted in high unspecific proliferation of both unstimulated CD4 $4^{+}$helper and CD8 $\alpha^{+}$cytotoxic $\mathrm{T}$ cells. This background proliferation is presumed to be the result of stimulation induced by fetal calf serum and can be reduced by using a serum-free medium (DALGAARD et al., 2010b). However, after removal of thrombocytes by combined dextran/ficoll separation, the background proliferation was significantly reduced even in medium containing $10 \%$ FCS, implicating a thrombocyte mediated mechanism. Thrombocytes have been shown to be major cytokine producers in chickens (SCOTT and OWENS, 2008) and both LPS and $\mathrm{CpG}$ oligodeoxynucleotides induced robust pro-inflammatory responses in thrombocytes (St PAUL et al., 2012), so one possible mechanism, through which they may 
M. Jergović et al.: Combined dextran and ficoll separation reduces thrombocyte contamination in isolated chicken peripheral blood mononuclear cells

affect background proliferation, is through bystander activation caused by their cytokine production. Due to high background proliferation, there was no statistically significant difference between unstimulated and antigen stimulated $\mathrm{T}$ cells proliferation after ficoll gradient separation alone. In contrast, after combined dextran/ficoll gradient separation, in both $\mathrm{CD}^{+}$helper and CD $8 \alpha^{+}$cytotoxic T cells, NDV induced proliferation was higher than in the unstimulated sample. Thus, our combined dextran/ficoll gradient separation revealed a reduction in background proliferation, which was not seen after ficoll gradient separation alone. However, at this point we cannot rule out an unspecific proliferation effect of the inactivated NDV antigen since naïve control chickens were not used.

$\%$ of proliferated cells in $\mathrm{CD} 4^{+}$and $\mathrm{CD} 8 \alpha^{+}$population

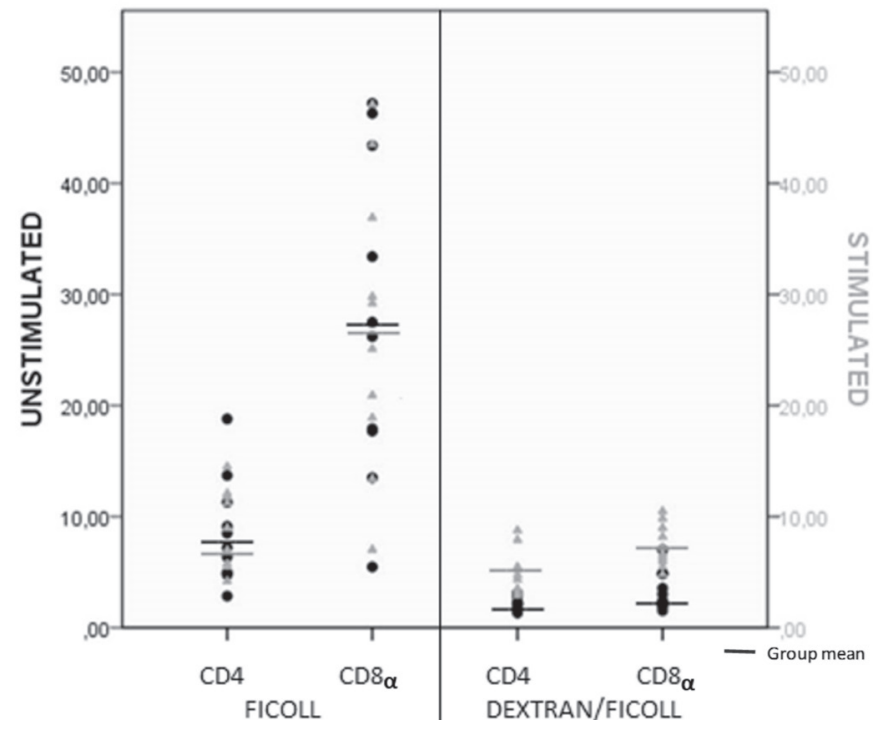

Fig. 2. T cell proliferation

There was no difference between proliferation of unstimulated (black dots) and NDV antigen stimulated T cells (grey triangles). After ficoll separation alone $\left(\mathrm{CD} 4^{+}, \mathrm{P}=0.938 ; \mathrm{CD} 8 \alpha^{+}, \mathrm{P}=\right.$ 0.74). After combined dextran/ficoll separation NDV-stimulated proliferation was higher in both $\mathrm{CD}^{+}(\mathrm{P}=0.02)$ and $\mathrm{CD} 8 \alpha^{+}(\mathrm{P}=0.00) \mathrm{T}$ cells, than unstimulated. Group means are shown as horizontal lines. Results were drawn from a total of 9 stimulated and 9 unstimulated samples of isolated PBMCs after cultivation and staining with antibodies of T-lymphocyte panel: CD3SPRD, CD8-FITC, CD4-R-PE, $\gamma \delta$ TCR-Alexa Fluor 647.

We also assessed dextran toxicity by comparing the number of dead cells in the unstimulated sample, and there was no difference between dextran/ficoll $(3.62 \%)$ and ficoll separation $(3.83 \% ; \mathrm{P}=0.58)$, indicating that dextran sedimentation is non-toxic. 
It is important to note that the critical step in our method is the removal of the upper layer containing PBMCs after the dextran slow spin centrifugation. This must be done carefully without affecting the bottom layer. Any disturbances of a monolayer by shaking the tubes or fast pipetting will result in higher thrombocyte contamination. It is better to leave approximately one third of the upper layer uncollected to avoid thrombocyte contamination that ultimately results in lower cell yield, as observed. However, this significantly reduces PBMC recovery, devoid of thrombocytes, and further optimization of the original protocol should be undertaken to increase PBMC separation efficiency. Our attempt to prolong the duration of the centrifugation step, resulted in sedimentation of the upper layer and led to loss of monocytes, which could affect the antigen presentation in the functional assay downstream. Dextran sedimentation alone should not be used as it results in significant erythrocyte and granulocyte contamination (data not shown). Thus, to obtain pure avian PBMCs for functional assays, the use of combined dextran/ficoll gradient separation should be considered.

In summary, we have devised a new method for isolating avian PBMCs which markedly reduces thrombocyte contamination, yields pure PBMCs and in turn improves the $\mathrm{T}$ cell proliferation assay in vitro by reducing background proliferation. Prospective assessment of antigen specific $T$ cell stimulation that includes both vaccinated and nonvaccinated control animals is required for further conclusions about dextran/ficoll cell separation effects.

\section{Acknowledgements}

This investigation was supported by grant No. 053-053-1863-1858 from the Ministry of Science and Technology of the Republic of Croatia.

\section{References}

BEIRÃO, B., C. FÁVARO, L. NAKAO, L. F. CARON, S. M. ZANATA, A. F. MERCADANTE (2012): Flow cytometric immune profiling of specific-pathogen-free chickens before and after infectious challenges. Vet. Immunol. Immunopathol. 145, 32-41.

BOHLS, R. L., R. SMITH, P. J. FERRO, N. J., SILVY, Z. LI, E. W. COLLISSON (2006): The use of flow cytometry to discriminate avian lymphocytes from contaminating thrombocytes. Dev. Comp. Immunol. 30, 843-850.

DALGAARD, T. S., L. R. NORUP, A. R. PEDERSEN, K. J. HANDBERG, P. H. JØRGENSEN, H. R. JUUL-MADSEN (2010a): Flow cytometric assessment of chicken T cell-mediated immune responses after Newcastle disease virus vaccination and challenge. Vaccine 28, 4506-4514.

DALGAARD, T. S., L. R. NORUP, D. RUBBENSTROTH, E. WATTRANG, H. R. JUULMADSEN (2010b): Flow cytometric assessment of antigen-specific proliferation in peripheral chicken T cells by CFSE dilution. Vet. Immunol. Immunopathol. 138, 85-94. 
M. Jergović et al.: Combined dextran and ficoll separation reduces thrombocyte contamination in isolated chicken peripheral blood mononuclear cells

De BOEVER, S., S. CROUBELS, K. DEMEYERE, B. LAMBRECHT, P. De BACKER, E. MEYER (2010): Flow cytometric differentiation of avian leukocytes and analysis of their intracellular cytokine expression. Avian Pathol. 39, 41-46.

FAIR, J., K. TAYLOR-McCABE (2008): Immunophenotyping of chicken peripheral blood lymphocyte subpopulations: Individual variability and repeatability. Vet. Immunol. Immunopathol. 125, 268-273.

LAVOIE, E. T., K. GRASMAN (2005): Isolation, cryopreservation, and mitogenesis of peripheral blood lymphocytes from chickens (Gallus domesticus) and wild herring gulls (Larus argentatus). Arch. Environ. Contam. Toxicol. 48, 552-558.

LUO, Q., C. CAI, X. XIE, X. CHU, Q., WU, X. MENG, F. ZOU (2010): Dextran sedimentation for study of neutrophil polarization. Nan Fang Yi Ke Da Xue Xue Bao 30, 1514-1517. (in Chinese)

SCOTT, T., M. D. OWENS (2008): Thrombocytes respond to lipopolysaccharide through Toll-like receptor-4, and MAP kinase and NF- $\mathrm{\kappa B}$ pathways leading to expression of interleukin- 6 and cyclooxygenase-2 with production of prostaglandin E2. Mol. Immunol. 45, 1001-1008.

SELIGER, C., B. SCHAERER, M. KOHN, H. PENDL, S. WEIGEND, B. KASPERS, S. HÄRTLE (2012): A rapid high-precision flow cytometry based technique for total white blood cell counting in chickens. Vet. Immunol. Immunopathol. 145, 86-99.

St. PAUL, M., S. PAOLUCCI, N. BARJESTEH, R. D. WOOD, K. A. SCHAT, S. SHARIF (2012): Characterization of chicken thrombocyte responses to toll-like receptor ligands. PLoS ONE 7(8): e43381.

SUSTROVA, T., P. ONDRACKOVA, L. LEVA, Z. SLADEK (2014): Isolation techniques of neutrophils and peripheral blood mononuclear cells for the comparative experiments in humans and pigs model organisms in flow cytometry. Mendel Net 1077, 516-521.

Received: 16 June 2016

Accepted: 19 January 2017

JERGOVIĆ, M., G. NEDELJKOVIĆ, Ž. CVETIĆ, Ž. GOTTSTEIN，K. BENDELJA: Kombinirana primjena dekstrana i fikola smanjuje udio trombocita u populaciji mononuklearnih stanica izdvojenih iz periferne krvi pilića - kratko priopćenje. Vet. arhiv 87, 623-630, 2017.

\section{SAŽETAK}

Metoda razdvajanja gradijentom gustoće pomoću fikola najčešće je korištena metoda za izdvajanje leukocita iz periferne krvi ptica, ali koja rezultira značajnom kontaminacijom trombocitima. Trombociti u populaciji izdvojenih stanica utječu na rezultate fenotipskih (imunofenotipizacija), ali i funkcionalnih testova $\mathrm{T}$ limfocita. Koristeći uzorke pune krvi od 10 cijepljenih muških pilića komercijalnog hibrida nesilica razvili smo metodu izdvajanja leukocita kombiniranom primjenom dekstrana i gradijenta gustoće pomoću fikola CD8aex vivo test proliferacije $\mathrm{T}$ limfocita pokazao je smanjenu pozadinsku proliferaciju nestimuliranih stanica nakon izdvajanja leukocita kombiniranom primjenom dekstrana i fikola.

Ključne riječi: dekstran, fikol, pilići, trombociti, leukociti 